\title{
Assessment of the Nutritional Status of 202 Elderly People Living at Home in Sidi-Bel-Abbès (Western Algeria)
}

\author{
Noureddine Menadi1, Ghozlane Kelkoul', Ilhem Hassani', Belabbes Merrakchi², \\ Slimane Belbraouet ${ }^{3 *}$ \\ ${ }^{1}$ Département de Biologie, Faculté des Sciences de la Nature et de la Vie, Université Djilali Liabès, \\ Sidi-Bel-Abbès, Algérie \\ ${ }^{2}$ Établissement Public de Santé de Proximité, Sidi Lahcen, Sidi-Bel-Abbès, Algérie \\ ${ }^{3}$ École des Sciences des Aliments, de Nutrition et d'Études Familiales (ESANEF), Université de Moncton, \\ Moncton, Canada \\ Email: ${ }^{*}$ slimane.belbraouet@umoncton.ca
}

Received 24 October 2014; revised 3 December 2014; accepted 18 December 2014

Copyright (C) 2015 by authors and Scientific Research Publishing Inc.

This work is licensed under the Creative Commons Attribution International License (CC BY). http://creativecommons.org/licenses/by/4.0/

(c) (i) Open Access

\section{Abstract}

Background: Malnutrition is common for elderly representing a major public health problem with many consequences for the health. Objectives: To assess the nutritional status of a population of elderly living at home. Subjects and Methods: The assessment was conducted from a population of elderly living at home who saw their doctor in the office of a public health centre. For each subject, the anthropometric parameters (weight, height, body mass index (BMI)), biochemical (serum albumin) and Mini Nutritional Assessment (MNA) tools have been measured and calculated. Results: 202 mostly female $(56.44 \%)$ subjects aged $73.59 \pm 5.87$ years were included in this study. $78 \%$ were suffering from chronic diseases, the most frequent of which was diabetes $(32 \%) .7 .43 \%$ of the diseased population have BMI $<21,5.94 \%$ experienced undernutrition (MNA $<17$ ) and $68.81 \%$ are at risk of malnutrition (MNA: 17 - 23.50). According to serum albumin, $8.91 \%$ of the sample is considered to be malnourished. Conclusion: The MNA has proven to be a screening tool more sensitive than other tools (BMI and albumin) in the evaluation of nutritional risk.

\section{Keywords}

Elderly, Nutritional Status, Anthropometric Parameters, Mini Nutritional Assessment, Albumin

\footnotetext{
${ }^{*}$ Corresponding author.
}

How to cite this paper: Menadi, N., Kelkoul, G., Hassani, I., Merrakchi, B. and Belbraouet, S. (2015) Assessment of the Nutritional Status of 202 Elderly People Living at Home in Sidi-Bel-Abbès (Western Algeria). Food and Nutrition Sciences, 6, 12-17. http://dx.doi.org/10.4236/fns.2015.61002 


\section{Introduction}

Malnutrition is common for older adults living at home, as dietary intake does not cover dietary need; malnutrition threatens nearly $30 \%$ of the elderly living at home. It represents a major public health problem and has many consequences for the health of the older person [1] [2]. Its prevalence is estimated to be approximately $4 \%$ to $10 \%$ for those living independently at home [3]. The malnutrition screening is based on the measurement of anthropometric and biological parameters and the use of nutritional indexes. The most commonly used parameters are the measurement of weight, the calculation of body mass index (BMI), the determination of albumin and pre-albumin [4] and the determination of the score of the Mini Nutritional Assessment (MNA) developed by Guigoz \& Velas [5]. The latter tool is widely used in the assessment of risk of malnutrition in different populations of elderly: hospitalised populations, preoperative, those convalescing in house retirement or those living at home [6]. Such studies in developing countries are rare and the nutritional assessments in diseased elderly are particularly scarce. Then, this study focuses on the evaluation of the nutritional status of 202 elderly living at home in Sidi-Bel-Abbès (Western Algeria) by using and comparing different tools: anthropometric parameters (weight, height, BMI), serum albumin and the MNA.

\section{Subjects and Methods}

This is a prospective study for 6 months (September to March 2013) in a Public Health Centre of the Sidi-BelAbbes (Western Algeria). The population studied consists in 202 elderly admitted to general medical consultation by their physicians. The inclusion criteria are age more or equal than 65 years for the both sexes. The exclusion criteria are disabled subjects and the mentally ill, the absence of verbal communication, the physical impossibility to weigh and measure the subject and the refusal of participation. The questionnaire included three parts: sociodemographic data, anthropometric parameters and clinical score. Weight is measured using an electronic balance with a precision of \pm 50 grams and a minimum of clothing. Height is measured in an upright position without shoes and heels using a wall rod. BMI is calculated from the mass of the weight and height and is expressed in $\mathrm{kg} / \mathrm{m}^{2}$. The MNA score is calculated for each subject. Serum albumin is performed by the colorimetric method (bromocresol green) [7] from the serum of subjects under fasting conditions. Chronic diseases of the elderly were diagnosed by treating physicians and medical records which are services of General Medicine at the establishment level.

The categories defined by the WHO [8] for BMI are underweight (BMI < 18.5), normal body (BMI: 18.5 24.99), overweight (BMI: 25 - 29.99) and obesity (BMI $\geq 30$ ). Malnutrition was defined by the presence of one or more of the following criteria: serum albumin less than $35 \mathrm{~g} / \mathrm{L}$ and/or a BMI below 21 or MNA less than 17 . Malnutrition was considered severe when albumin was less than $30 \mathrm{~g} / \mathrm{L}$ or BMI was less than 18 [9]. The risk of malnutrition is estimated by the score of screening of the MNA 17 - 23.50 [3] [10] [11].

Statistical analysis was performed using the StatView 5 program (SAS Institute) [12]. Continuous variables are expressed as mean \pm standard deviation. The qualitative variables are presented in the form of numbers and percentages. Nutritional index and anthropometric, biological parameter results are interpreted using the reference intervals previously established in elderly subjects. The comparison between the two groups is performed by the paired Student's t-test for mean comparisons after checking the normal distribution of the study sample. Simple regression analysis is used to deduce the correlation coefficient between variables. The significance threshold is $5 \%$. All the elderly subjects gave their informed consent to participate in the study.

\section{Results}

At the end of the study period, 202 subjects living at home (88 men and 114 women) were included. The average age was $73.59 \pm 5.87$ years (Table 1 ). No significant differences were detected between the ages of women (73.46 \pm 6.26 years) and men (73.77 \pm 5.35 years). The average weight of participants was $68.20 \pm 13.15 \mathrm{~kg}$ (women: $65.85 \pm 12.86 \mathrm{~kg}$; men: $71.25 \pm 12.97 \mathrm{~kg}$ ), average height was $1.59 \pm 0.10$ meters (women: $1.53 \pm 0.07$ meters, men: $1.68 \pm 0.08$ meters) and the BMI was $26.91 \pm 4.96 \mathrm{~kg} / \mathrm{m}^{2}$. Significant differences were observed between men and women for weight, height, and BMI $(p<0.05)$. There were no significant differences for serum albumin and MNA between the sexes. All the subjects lived with family. The majority of the study population (78\%) had chronic diseases: diabetes (32\%), hypertension (25\%), cardiovascular diseases (12\%) and 9\% other (asthma (2\%) and rheumatism (7\%)).

Malnutrition, as detected by the BMI, was $7.43 \%$ (women: $8.77 \%$, men: $5.68 \%$ ) with severe malnutrition at $1 \%$ 
(women: 0\%; men: 2.27\%). According to serum albumin, 8.91\% of the sample (women: $7.02 \%$; male: 11.36\%) was malnourished (albumin $<35 \mathrm{~g} / \mathrm{L}$ ) and 3.46\% (women: 2.63\%; men: 4.54\%) was severely malnourished (albumin $<30 \mathrm{~g} / \mathrm{L}$ ). The MNA indicated that $68.81 \%$ of subjects were at risk of malnutrition (MNA: $17-23.50$ ) and $5.94 \%$ (9.65\% of women and $1.14 \%$ of men) were malnourished (MNA < 17) (Table 2). BMI results divided into the categories defined by the WHO [9] highlight that $1.49 \%$ of the population concerned are considered underweight, $37.62 \%$ had a normal weight, $37.13 \%$ were overweight, and $23.76 \%$ were obese.

An inverse correlation appears between the age and the anthropometric parameters (height, weight, and BMI) in both groups. Regarding the correlation between age, MNA and albumin, it is inversely correlated among women and positively correlated in males (Table 3).

Table 1. Anthropometric parameters, serum albumin, and MNA in the studied population.

\begin{tabular}{cccc}
\hline & Total population & Women & Men \\
\cline { 2 - 3 } Healthy (\%) & $(\mathrm{n}=202)$ & $(\mathrm{n}=114)$ & $(\mathrm{n}=88)$ \\
Diseased (\%) & 22 & 14 & 33 \\
Diabetes & 78 & 86 & 67 \\
Hypertension & 32 & 35 & 28 \\
MCV & 25 & 26 & 9 \\
Others & 12 & 14 & 6 \\
Lifestyle & 9 & 11 & - \\
Alone & - & $-14(100 \%)$ & $88(100 \%)$ \\
With family & $202(100 \%)$ & $73.46 \pm 6.26$ & $73.77 \pm 5.35$ \\
Age (years) & $73.59 \pm 5.87$ & $65.85 \pm 12.86 *$ & $71.25 \pm 12.97$ \\
Body weight (kg) & $68.20 \pm 13.15$ & $1.53 \pm 0.07^{*}$ & $1.68 \pm 0.08$ \\
Height (m) & $1.59 \pm 0.10$ & $28.20 \pm 5.41^{*}$ & $25.24 \pm 3.70$ \\
BMI (kg/m $\left.{ }^{*}\right)$ & $26.91 \pm 4.96$ & $43.53 \pm 6.86$ & $42.16 \pm 6.48$ \\
Albumin (g/L) & $42.93 \pm 6.72$ & $19.46 \pm 3.35$ & $18.91 \pm 4.50$ \\
MNA & $19.22 \pm 3.89$ & 9.65 & 1.14 \\
MNA $<17$ (\%) & 5.94 & 76.32 & 59.09 \\
MNA: 17 - 23.5 (\%) & 68.81 & 14.03 & 39.77 \\
MNA $>$ 23.50 (\%) & 25.25 & & 9 \\
\hline
\end{tabular}

${ }^{*} p<0.05$; CVD: cardiovascular diseases; BMI: body mass index; MNA: Mini Nutritional Assessment.

Table 2. Prevalence of malnutrition using BMI, serum albumin, and MNA.

\begin{tabular}{ccccc}
\hline & Total population & Women & Men & $p$ value \\
\cline { 2 - 4 } & 202 & 114 & 88 & - \\
\hline Risk of malnutrition (\%) & & & & $<0.05$ \\
MNA: $17-23.50$ & 68.81 & 76.32 & 59.09 & $<0.05$ \\
Moderate malnutrition (\%) & & & NS \\
BMI $<21 \mathrm{~kg} / \mathrm{m}^{2}$ & 7.43 & 8.77 & 5.68 & $<0.05$ \\
Albumin $<35 \mathrm{~g} / \mathrm{L}$ & 8.91 & 7.02 & 11.36 & 1.14 \\
MNA $<17$ & 5.94 & 9.65 & & $<0.05$ \\
Severe malnutrition (\%) & & & 2.27 & $<0.05$ \\
BMI $<18 \mathrm{~kg} / \mathrm{m}^{2}$ & 1 & 0 & 4.54 & \\
Albumin $<30 \mathrm{~g} / \mathrm{L}$ & 3.46 & 2.63 & & \\
\hline
\end{tabular}

BMI: body mass index; MNA: Mini Nutritional Assessment; NS: non-significant. 
Table 3. Correlation coefficient between age, MNA, anthropometric parameters, and serum albumin.

\begin{tabular}{|c|c|c|c|c|c|c|}
\hline \multicolumn{7}{|c|}{ Women $(n=114)$} \\
\hline & Age (y) & Body weight (kg) & Height (m) & BMI $\left(\mathrm{kg} / \mathrm{m}^{2}\right)$ & Albumin (g/L) & MNA \\
\hline Age (y) & - & -0.386 & -0.14 & -0.333 & -0.041 & -0.111 \\
\hline MNA & -0.111 & -0.152 & -0.062 & 0.22 & 0.003 & - \\
\hline \multicolumn{7}{|c|}{ Men $(n=88)$} \\
\hline & Body weight (kg) & Height (m) & BMI $\left(\mathrm{kg} / \mathrm{m}^{2}\right)$ & Albumin (g/L) & MNA & \\
\hline Age (y) & - & -0.265 & -0.374 & -0.083 & 0.084 & 0.042 \\
\hline MNA & 0.042 & -0.152 & -0.048 & -0.124 & -0.061 & - \\
\hline
\end{tabular}

BMI: body mass index; MNA: Mini Nutritional Assessment; SA: serum albumin.

\section{Discussion}

Our study, conducted in a population of elderly people living at home, found a high prevalence of diabetes (32\%) far greater than that described in the literature (10\%) for industrialized countries [13]-[15] but similar to that found in a previous study in Algerian population [16]. BMI in both males and females conforms to the standards proposed by Beck et al. (24 - $\left.29 \mathrm{~kg} / \mathrm{m}^{2}\right)$ [17] and the values accepted by the European Community of Gerontology [18]. Among women, the BMI is similar and comparable to the data from the literature [19] [20]. The average value of serum albumin of the study population is similar to that reported in industrialized countries [21] [22] [23] but higher than that observed in an Algerian population [16]. BMI scores indicated that $7.43 \%$ of the subjects were undernourished; this prevalence is similar to that described in the literature (5\% - 10\%) [24] [25]. The serum albumin values of the study population indicated that $8.91 \%$ were malnourished, with a prevalence that was different in both sexes (women: 7.02\% versus men: $11.36 \%$ ). Severe malnutrition detected by serum albumin is greater among men than among women (4.54\% versus $2.63 \%$ ). This is consistent with the work of Elasmi-Allal et al. [26]; however, this frequency is greater than that reported in the literature in the elderly living at home [27]. According to the MNA, 5.94\% of the study were malnourished, which is comparable to data from the literature [25] and $68.81 \%$ of subjects were at nutritional risk, which is much greater than the data in the literature [2]. It is worth noting that the prevalence of high nutritional risk observed in our study is confirmed by the work of Menadi et al. [16] in an Algerian population. Women are more exposed to the risk of malnutrition than men (76.32\% versus 59.09\%); these results are in agreement with Kezachian \& Bonnet [2].

The prevalence of obesity in the study population is similar to that previously observed in an Algerian population [16]; it was also higher among women (34.21\%) than men $(10.23 \%)(p<0.05)$. This finding is consistent with the work of Elasmi-Allal et al. [26] and Serra et al. [23]. However, the frequency of obesity in our study is greater than that described by the French investigator, Obépi [28], and other works that led to similar results [13] [27]. BMI was inversely correlated with age among women and among men, -0.333 and -0.083 respectively; these results are consistent with the work of Tavitian et al. [29] and Belbraouet et al. [15]. The MNA was correlated with age in males; this is consistent with Vellas et al. [30], however it was not correlated with age in women. This result is in agreement with Chumlea et al. [31] and in contradiction to Salleti et al. [32].

Serum albumin was inversely correlated with age in women $(-0.041)$ and had no correlation among men (0.084). This corroborates the results of Klonnoff-Cohen et al. [33]. Kezachian et al. [2] reported that the prevalence of nutritional risk or malnutrition varies based on the screening tool used, especially when the objective of the tool is to identify those at nutritional risk or malnourished.

\section{Conclusion}

The MNA is more sensitive than BMI and serum albumin in the detection of persons at risk of malnutrition. This is supported by the work of Vellas et al. [34] and Guigozet Vellas [35] and the results raise the question of the nutritional value of support of the elderly living at home.

\section{References}

[1] Mallay, D. (2011) Simplification de la stratégie de dépistage de la dénutrition du sujet très âgé en EHPAD: Un pari sur 
la pesée mensuelle. Neurologie-Psychatrie-Gériatrie, 11, 76-83. http://dx.doi.org/10.1016/j.npg.2010.12.007

[2] Kézachian, L. and Bonnet, P.-A. (2012) Simplifying Screening Process of Elderly Malnutrition in General Practice: Test Match between a Simple Tool, the "Malnutrition Universal Screenig Tool" (MUST) and the "Mini Nutritional Assessment-Short Form” (MNA-SF). Nutrition Clinique et Métabolisme, 26, 109-113. http://dx.doi.org/10.1016/j.nupar.2012.07.004

[3] Patry, C. and Raynaud-Simon, A. (2011) Prise en charge de la dénutrition chez les personnes âgées: Quoi de neuf depuis les recommandations de l’HAS en 2007. Neurologie-Psychatrie-Gériatrie, 11, 95-100. http://dx.doi.org/10.1016/j.npg.2011.03.003

[4] Dagorne, C., David, S., Alix, E., Girard, D., Bouzillé, G., Tallec, A. and Fanello, S. (2011) Prévention et prise en charge de la malnutrition dans les EHPAD. Cahiers de Nutrition et de Diététique, 46, 137-144. http://dx.doi.org/10.1016/j.cnd.2011.02.001

[5] Guigoz, Y. and Vellas, B. (1995) Test d'évaluation de l'état nutritionnel de la personne âgée: Le Mini Nutritional Assessment (MNA). Médecine Hygiène, 53, 1965-1969.

[6] Vellas, B., Villars, H., Abellan, G., Soto, M.E.R., Rolland, Y., Guigoz, Y., Morley, J.E., et al. (2006) Overview of the MNA. Its History and Challenges. Journal of Nutrition Health and Aging, 10, 456-463.

[7] Doumas, B.T., Watson, W.A. and Biggs, H.G. (1971) Albumin Standards and the Measurement of Serum Albumin with Bromocresolgreen. Clinica Chimica Acta, 31, 87-96. http://dx.doi.org/10.1016/0009-8981(71)90365-2

[8] OMS (2014) Obésité et surpoids. http://www.who.int/mediacentre/factsheets/fs311/fr/

[9] Raynaud, A., Revel-Delhom, C., Alexandre, D., Alix, E., Ancellin, R., Bouteloup, C., Brocker, P., Chapiro, S., Dumarcet, H.A., Lecocq, J.-M., Lefévre, M.-P., L’Herminze, A., Lurcel, J., Ménivard, N., Perette, M.-A. and Hébuterne, X. (2007) Recommandations professionnelles. HAS. Stratégie de prise en charge en cas de dénutrition protéino-énergétique chez la personne âgée. Nutrition Clinique et Metabolisme, 21, 120-133. http://dx.doi.org/10.1016/j.nupar.2007.07.004

[10] Raynaud-Simon, A. (2009) Comment dépister la malnutrition chez la personne âgée? Médecine des Maladies Métaboliques, 3, 365-369.

[11] Blonde-Cynober, F. and Aussel, C. (2010) Définition des intervalles de référence des seuils décisionnels chez les sujets âgés: Cas de l'évaluation de l'état nutritionnel. Bio Tribune Magazine, 35, 15-19.

[12] Caldorola, J., Dilmaghani, A., Gagnon, J., Soper, C. and Wasserman, E. (1998) StatView for Windows Version 5: Cary, NC 27513. SAS Institute Inc.

[13] Bourdel-Marchasson, I. and Traissac, T. (2004) Place et impact des régimes chez les personnes les plus âgées. Nutrition Clinique et Métabolisme, 18, 224-230. http://dx.doi.org/10.1016/j.nupar.2004.09.003

[14] Muller, H., Denis, B., Valentin, C. and Teillet, L. (2004) Human Ageing: Demographic Trends and Medical Implications. Nutrition Clinique et Métabolisme, 18, 171-174. http://dx.doi.org/10.1016/j.nupar.2004.10.004

[15] Belbraouet, S., Chau, N., Tebi, A. and Debry, G. (2011) Anthropometric Characteristics of Hospitalized Elderly Women: A Case-Control Study. International Journal of Environmental Research and Public Health, 8, 2584-2592. http://dx.doi.org/10.3390/ijerph8072584

[16] Menadi, N., Khaled, M.B., Merrakchi, B. and Belbraouet, S. (2013) Nutritional Status of Elderly People Living at Home in Sidi-Bel-Abbes (West Algeria). Food and Nutrition Sciences, 4, 860-865. http://dx.doi.org/10.4236/fns.2013.48112

[17] Beck, A.M. and Ovesen, L. (1998) At Which Body Mass Index and Degree of Weight Loss Should Hospitalized Elderly Patients Be Considered at Nutritional Risk. Clinical Nutrition, 17, 195-198. http://dx.doi.org/10.1016/S0261-5614(98)80058-7

[18] Schlienger, J.-L., Luca, F. and Pradignac, A. (2009) Particularité de l’obésité chez la personne âgée. Médecine des Maladies Métaboliques, 3, 375-379.

[19] De Groot, C.G.P.M., Enzi, G., Perdiago, A.L. and Deurenberg, P. (1996) Longitudinal Changes in Anthropometric Characteristics of Elderly Europeans. Seneca-Investigators. European Journal of Clinical Nutrition, 50, S9-S15.

[20] Karen, E., Charlton, P.-D., Tracy, L., Kolbe-Alexander, P.-D., Johanna, H. and Nel, G.H. (2007) The MNA, but Not the Determine, Screening Tool Is a Valid Indicator of Nutritional Status in Elderly Africans. Nutrition, 23, 533-542. http://dx.doi.org/10.1016/j.nut.2007.04.015

[21] Nes, M., Lund-Larsen, K., Trygg, K., Høviq, H.O. and Pedersen, I. (1993) Nutrition and the Elderly in Europe: Low Prevalence of Obesity and Biochemical Deficiencies in Norwegian Subjects. Age and Nutrition, 4, 72-81.

[22] Gatto, M., Inelmen, E.-M., Ferrari, S., Jimenez, G.-F., Bisbini, P.-L. and Enzi, G. (1996) Nutrients Intake in Elderly: Descriptive Results of a Cross-Sectional Study. Age and Nutrition, 6, 17-23.

[23] Serra, J.A., Baeza, E., Cruz-Jentoft, A.J., Alcalade, P., Sanchez-Diez, A., Romeo, S., Cabrerizo, L. and Ribera, J.M. 
(1993) Nutritional Status and Nutritional Intake in Non-Hospitalized Elderly. Age and Nutrition, 4, 82-87.

[24] Mowé, M., Bohmer, T. and Kindt, E. (1994) Reduced Nutritional Status in an Elderly Population (>70 y) Is Probable before Disease and Possibly Contributes to the Development of Disease. The American Journal of Clinical Nutrition, 59, 317-324.

[25] Noel, D. (1998) Stratégie nutritionnelle en médecine gériatrique. Louvain Medical, 117, S47-S51.

[26] Elasmi-Allal, M., Sanhadji, H., Jemma, R., Jemma, A., Kaabachi, N. and Mebazaa, A. (2003) Etude de l'état nutritionnel des personnes âgées dans deux populations tunisiennes séjournant à domicile ou en institution. La Revue de gériatrie, 28, 39-36.

[27] Macia, E., Boetsch, G., Chauis-Lucciani, N. (2004) Etude anthropométrique du vieillissement dans une population âgée française (Marseille): Relation entre l'âge, l'indice de masse corporelle, acuité visuelle et des facteurs sociopsychologiques. Antropo, 7, 113-122. www.didac.ehu.es/antropo

[28] Quilliot, D., Böhme, P., Malgras, A. and Ziegler, O. (2013) L’obésité du sujet âgé. Nutrition Clinique et Métabolisme, 27, 95-101. http://dx.doi.org/10.1016/j.nupar.2013.03.003

[29] Tavitian, P., Tosello, A., Videau, L., Cornubert, L. and Bonfil, J.J. (2010) Etat bucco-dentaire et statut nutritionnel: Etude anthropo-épidémiologique chez les personnes âgées. Antropo, 22, 19-28. www.didac.ehu.es/antropo

[30] Vellas, B., Guigoz, Y., Baumgartner, M., Garry, P.J., Lauque, S. and Albarède, J.L. (2000) Relationships between Nutritional Markers and the Mini Nutritional Assessment in 155 Older Persons. Journal of the American Geriatrics Society, 48, 1300-1309.

[31] Chumlea, W.C., Hall, G., Lilly, F., Siervogel, R.M. and Guo, S.S. (1999) The Mini Nutritional Assessment and Body Composition in Healthy Adults. Nestlé Nutrition Workshop Series Clinical \& Performance Programme, 1, 13-22. http://dx.doi.org/10.1159/000062956

[32] Saletti, A., Lindgren, E.Y., Johansson, L. and Cederholm, T. (2000) Nutritional Status according to Mini Nutritional Assessment in an Institutionalized Elderly Population in Sweden. Gerontology, 46, 139-145. http://dx.doi.org/10.1159/000022149

[33] Klonoff-Cohen, H., Barrett-Connor, E.L. and Edelstein, S.L. (1992) Albumin Levels as a Predictor of Mortality in the Healthy Elderly. Journal of Clinical Epidemiology, 45, 207-212. http://dx.doi.org/10.1016/0895-4356(92)90080-7

[34] Vellas, B., Guigoz, Y., Garry, P.J., Nourhashemi, F., Bennahum, D. and Lauque, S. (1999) The Mini Nutritional Assessment (MNA) and Its Use in Grading the Nutritional State of Elderly Patients. Nutrition, 15, 116-122. http://dx.doi.org/10.1016/S0899-9007(98)00171-3

[35] Guigoz, Y. and Vellas, B. (1999) The Mini Nutritional Assessment (MNA) for Grading the Nutritional State of Elderly Patients: Presentation of the MNA, History and Validation. Nestlé Nutrition Workshop Series Clinical \& Performance Programme, 1, 3-12. http://dx.doi.org/10.1159/000062967 
Scientific Research Publishing (SCIRP) is one of the largest Open Access journal publishers. It is currently publishing more than 200 open access, online, peer-reviewed journals covering a wide range of academic disciplines. SCIRP serves the worldwide academic communities and contributes to the progress and application of science with its publication.

Other selected journals from SCIRP are listed as below. Submit your manuscript to us via either submit@scirp.org or Online Submission Portal.
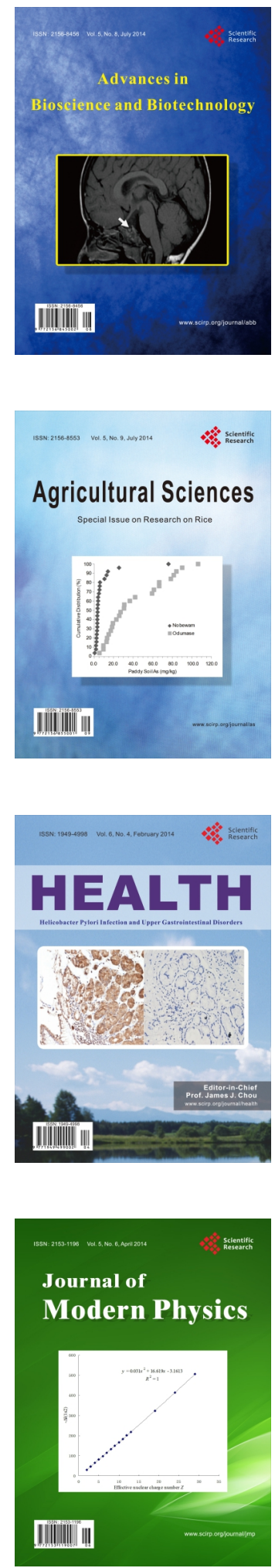
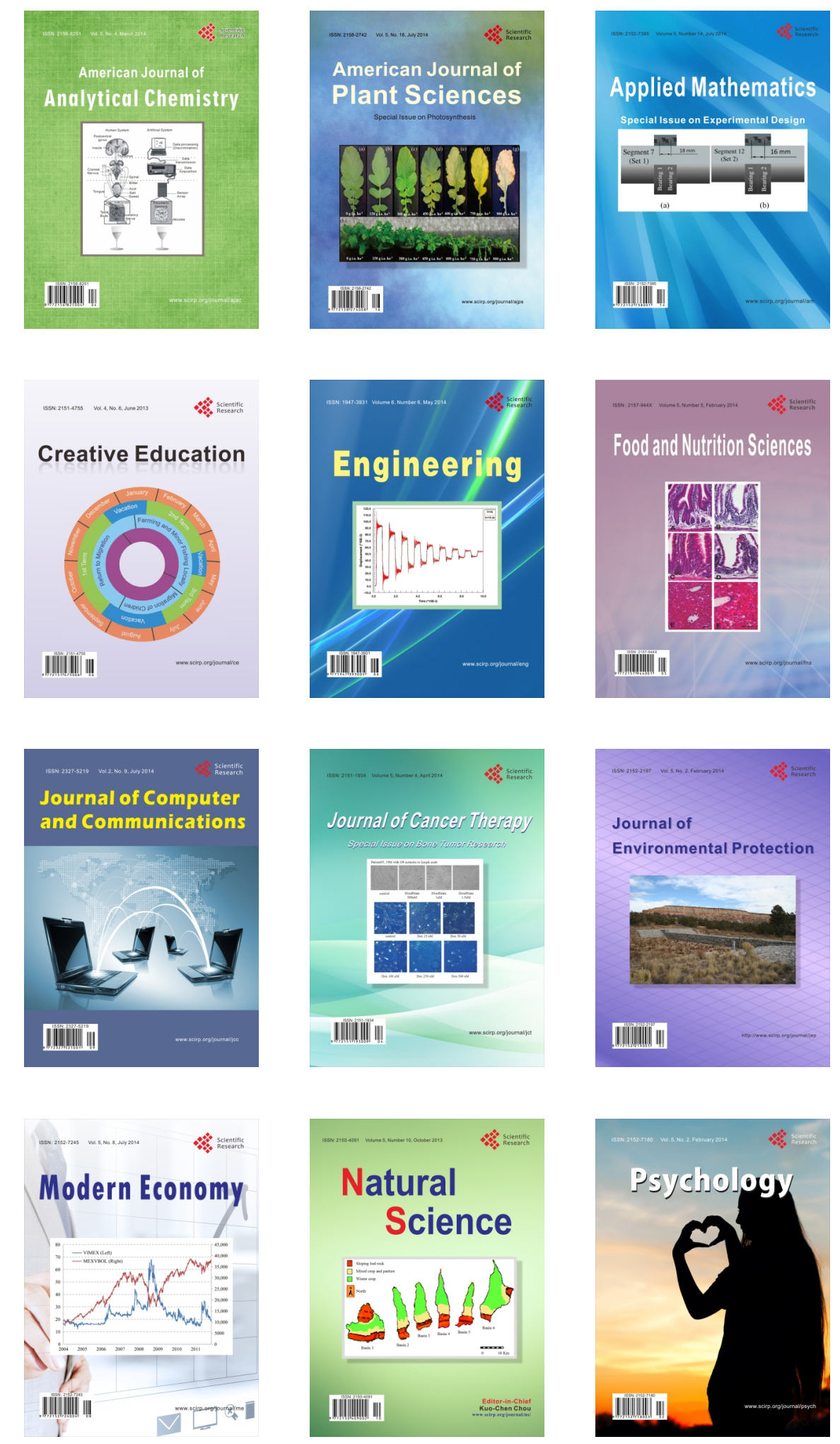